\title{
ANALISIS KEMAMPUAN PEMECAHAN MASALAH PADA MODEL PROBLEM BASED LEARNING DISERTAI REMEDIAL TEACHING
}

\author{
Samsul Arifin ${ }^{a x}$, Kartono $^{b}$, Isti Hidayah ${ }^{c}$ \\ a SMA Negeri 1 Bojong Kabupaten Tegal, Jawa Tengah, 52465, Indonesia \\ b,c Prodi Pendidikan Matematika, Program Pascasarjana, Universitas Negeri Semarang, Indonesia \\ ${ }^{\text {xCCorresponding author: s4ms121266@gmail.com }}$
}

\begin{abstract}
The purpose of this research are (1) to analyze the learning quality of problem based learning model which is accompanied by gave remedial teaching, (2) to described remedial teaching process a follow up diagnostic assessment, and (3) to analyze the ability of solving mathematical problems students are reviewed from cognitive style. This research is a mixed method research of concurrent embedded types. The research population were students of class XI MIPA SMA 1 Bojong Tegal. The result of mathematical problem solving ability test was analyzed qualitatively using mean test, comprehensive test, mean deviation test, and deviation proportion test Result of this research shows learning quality of PBL learning model with remedial teaching is considered well both qualitatively and quantitatively. The provision of diagnostic tests and remedial teaching treatment is effective to improve problem solving abilities, and the problem solving ability of independent field students is better than field dependent students.
\end{abstract}

Keywords: Mathematical Problem Solving Ability, Problem Based Learning (PBL), Cognitive Style, jggjbRemedial Teaching, Diagnostic assessment.

\section{PENDAHULUAN}

Pendidikan merupakan salah satu hal terpenting demi kemajuan suatu bangsa. Permendikbud Nomor 21 Tahun 2016 tentang standar isi pendidikan dan menengah menyatakan bahwa pelajaran matematika perlu diberikan kepada semua peserta didik dimulai dari sekolah dasar. Hal tersebut dikarenakan matematika sangat berguna dalam semua aspek kehidupan manusia (Akinmola, 2014).

Standar kemampuan matematika yang harus dicapai menurut NCTM (2000) yaitu penalaran matematis, representasi matematis, komunikasi matematis, pengaitkan ide-ide matematis, pemecahan masalah. Kemampuan pemecahan masalah merupakan aspek terpenting yang harus dimiliki oleh peserta didik.

Belajar pemecahan masalah merupakan tujuan utama dari pembelajaran matematika, karena masalah merupakan fakta tak terhindarkan dalam kehidupan manusia. National Council of Teacher Mathematics (NCTM, 2000) menyatakan bahwa dalam pembelajaran matematika diharapkan peserta didik mampu: membangun pengetahuan baru matematika melalui pemecahan masalah; memecahkan masalah yang timbul dengan melibatkan matematika dalam konteks lain; menerapkan dan menyesuaikan berbagai macam strategi yang cocok untuk memecahkan masalah; dan mengamati dan mengembangkan proses pemecahan masalah. Pentingnya kemampuan pemecahan masalah matematika belum diimbangi dengan prestasi Indonesia di bidang matematika. Hal tersebut dapat terlihat dari hasil keikutsertaan Indonesia dalam asesmen utama berskala internasional yaitu PISA (Programme for International Student Assessment) dan 
TIMSS (Trend in Internasional Mathematics and Science Survey).

Dari hasil International Survei Program for International Student Assessment (PISA) tahun 2012, Indonesia menempati peringkat 64 dari 65 negara peserta PISA (OECD, 2012). Pada tahun 2015, Indonesia masih menempati peringkat 56 dari 65 negara peserta PISA dalam kemampuan menghitung, membaca dan sains (OECD, 2015). Sedangkan hasil survey internasional TIMSS (Trend in Internasional Mathematics and Science Survey). Pada tahun 2015, Indonesia menduduki peringkat 49 dari 53 negara peserta TIMSS. Berdasarkan hasil survey TIMSS (2015), presentase kemampuan matematika peserta didik di Indonesia bahwa kemampuan pemecahan masalah matematika peserta didik di Indonesia masih di bawah standar Internasional.

Rendahnya kemampuan pemecahan masalah matematika peserta didik berdasarkan hasil studi PISA dan TIMSS tersebut diperkuat dengan realita yang ada di sekolah. Hasil observasi awal yang dilakukan di SMA Negeri 1 Bojong diperoleh informasi bahwa peserta didik masih mengalami kesulitan dalam menyelesaikan soal pemecahan masalah matematika, peserta didik mengalami kesulitan dalam menyelesaikan dan memahami soal cerita yang bersubstansi kontekstual, peserta didik juga salah dalam menentukan langkah-langkah penyelesaian yang digunakan sebagai strategi untuk menyelesaikan permasalahan. Menurut Joseph (2011) kesulitan pemecahan masalah matematika peserta didik dikarenakan kurangnya pemahaman dari masalah yang ditimbulkan, kurangnya pengetahuan strategi pemecahan, dan ketidakmampuan untuk menerjemahkan masalah ke dalam bentuk matematika.

Dalam memecahkan masalah matematika, setiap orang memiliki karakteristik yang khas, yang tidak dimiliki oleh individu lain. Perbedaan karakteristik dari setiap individu dalam menanggapi informasi, merupakan gaya kognitif individu yang bersangkutan. Menurut Witkin,et al.,(1977) gaya kognitif dalam belajar matematika adalah gaya kognitif field independent dan field dependent. Pembelajaran yang inovatif diperlukan untuk mendukung peningkatan kemampuan pemecahan masalah. Salah satu pembelajran yang dapat diterapkan untuk mengembangkan kemampuan pemecahan masalah ialah model problem based learning (PBL). Hmelo-Silve (2004) menyatakan bahwa problem based learning adalah metode pembelajaran dimana peserta didik belajar melalui suatu masalah untuk memecahkan masalah tersebut. Hal ini sesuai dengan hasil penelitian Noriza, et al.,(2015) yang menyatakan model pembelajaran berbasis masalah efektif terhadap kemampuan pemecahan masalah. Hal ini sejalan dengan hasil penelitian Abdullah, et al., (2015) menyatakan bahwa model pembelajaran problem based learning dapat meningkatkan kemampuan pemecahan masalah matematika.

Pada dasarnya, setiap pembelajaran baik menggunakan model pembelajaran konvensional maupun model pembelajaran problem based learning dalam proses belajar mengajar selalu ada hambatan dan kendala. Salah satu kendala yang masih terjadi di pembelajaran matematika adalah peserta didik masih mengalami kesulitan belajar sehingga peserta didik tidak mampu mencapai ketuntasan belajar. Untuk mengatasi kesulitan-kesulitan yang terjadi, maka setiap pembelajaran diakhiri dengan tes diagnostik yang gunanya untuk menganalisis kesulitan peserta didik. Sehingga dapat terdeteksi peserta didik manakah yang masih kesulitan pada materi yang diajarkan saat menggunakan model problem based learning. Menurut Satoto (2013) seorang guru dalam pembelajaran guru harus mengenal dan memahami peserta didik dengan baik, memahami keunggulan dan kekurangannya. Hal ini sesuai pendapat Khaerunisak, et al., (2017) yang menyatakan seorang guru hendaknya menganalisis kesulitan peserta didik terlebih dahulu sebelum melanjutkan pada materi berikutnya. Hasil tes diagnostik dapat memberikan informasi tentang konsep-konsep yang belum dipahami dan yang telah dipahami.

Setelah mengetahui kesulitan peserta didik, maka tugas seorang guru harus membantu peserta didiknya dalam mengatasi kesulitan tersebut, yaitu salah satunya dengan pemberian perlakuan remedial teaching. Menurut Mulyadi (2010) 
pengajaran remedial adalah pengajaran khusus yang memperbaiki kemampuan peserta didik dari kesulitan-kesulitan yang dihadapi. Dari hasil observasi dan wawancara pada umumnya remedial teaching yang dilaksanakan guru hanya sebatas pada pengulangan pembelajaran yang telah dilakukan sebelumnya, tanpa adanya penanganan khusus terhadap kesulitan belajar yang dialami peserta didik. Sehingga pembelajaran remedial yang diartikan sebatas "mengulang tes" jelas tidak tepat, karena kesulitan-kesulitan yang dialami peserta didik tentu tidak akan teratasi dengan hanya mengerjakan soal yang sama.

Berdasarkan uraian di atas, tujuan dari penelitian ini adalah: (1) menganalisis kualitas pembelajaran model problem based learning yang disertai pemberian perlakuan berupa remedial teaching terhadap kemampuan pemecahan masalah matematika, (2) mendeskripsikan proses remedial teaching sebagai tindak lanjut hasil asesmen diagnostik, dan (3) menganalisis kemampuan pemecahan masalah matematika peserta didik ditinjau dari gaya kognitif pada pembelajaran model problem based learning yang disertai dengan pemberian perlakuan remedial teaching pada materi program linear.

\section{KAJIAN PUSTAKA}

\section{Kemampuan Pemecahan Masalah Matematika}

Pemecahan masalah merupakan bagian yang sangat penting dalam pembelajaran matematika. Pemecahan masalah merupakan bagian dari kurikulum matematika yang sangat penting karena dalam proses pembelajaran maupun penyelesaian, peserta didik dimungkinkan memperoleh pengalaman menggunakan pengetahuan serta keterampilan yang sudah dimiliki untuk diterapkan pada pemecahan masalah yang bersifat tidak rutin (Suherman, 2003).

Dalam pemecahan masalah biasanya melibatkan beberapa kombinasi konsep dan keterampilan dalam suatu situasi baru atau situasi yang berbeda. Menurut Polya (Suherman, 2003), solusi soal pemecahan masalah memuat empat langkah penyelesaian, yaitu: memahami masalah (understanding the problem); merencanakan pemecahan (devising a plan); melakukan perhitungan (carrying out the plan); dan memeriksa kembali (looking back). Dengan mengacu pada keempat tahapan Polya tersebut kemudian dapat dianalisis tingkat kemampuan pemecahan masalah peserta didik.

Berdasarkan NCTM (2000) terdapat beberapa indikator pemecahan masalah yaitu membangun pengetahuan baru melalui pemecahan masalah, memecahkan masalah dengan melibatkan matematika dalam konteks lain, menerapkan berbagai startegi yang tepat untuk memecahkan masalah dan merefleksikan proses dalam pemecahan masalah matematika. Pada penelitian ini, pemecahan masalah dianggap merupakan standar kemampuan yang harus dimiliki para peserta didik setelah menyelesaikan suatu proses pembelajaran. Kemampuan pemecahan masalah merupakan kemampuan yang menjadi target pembelajaran matematika dan terukur. Pengukuran kemampuan pemecahan masalah didasarkan pada proses yang dilakukan oleh peserta didik. Dengan kata lain langkah-langkah pengerjaan peserta didik dalam menyelesaikan soal-soal harus dihargai seadil-adilnya berdasarkan penilaian yang objektif.

\section{Gaya Kognitif}

Setiap individu mempunyai cara khas sendiri-sendiri, sehingga setiap individu berbeda satu dengan lainnya. Kemampuan setiap individu untuk memahami dan menyerap pelajaran juga berbeda, ada yang cepat, sedang, dan ada yang lambat. Oleh karena itu, setiap individu seringkali harus menempuh cara berbeda untuk bisa memahami sebuah informasi. Perbedaan tersebut disebabkan oleh beberapa faktor dan salah satunya adalah gaya kognitif.

Witkin (1973) mengungkapkan bahwa gaya kognitif dikategorikan menjadi gaya kognitif field independent dan field dependent. Peserta didik dengan gaya kognitif field independent cenderung memilih belajar individual, menanggapi dengan baik, dan bebas (tidak bergantung pada orang lain). Sedangkan, peserta didik yang memiliki gaya kognitif field dependent cenderung memilih belajar dalam kelompok dan sesering mungkin berinteraksi dengan peserta didik lain atau guru, memerlukan 
ganjaran atau penguatan yang bersifat ekstrinsik. Crozier (1997) mengatakan bahwa perbedaan gaya kognitif field independent dan field dependent dapat diteliti menggunakan alat ukur EFT (Embedded Figures Test) atau RFT (Rodand-Frame Test). Witkin (1973) mengembangkan EFT ini menjadi GEFT (Group Embeded Figure Test). Pada penelitian ini, peneliti menggunakan tes GEFT.

\section{Model Problem Based Learning (PBL)}

Pemecahan masalah merupakan bagian dari kurikulum matematika yang sangat penting terutama dalam proses pembelajaran maupun penyelesaian. Peserta didik dapat memperoleh pengalaman melalui proses pembelajaran. Pengalaman, pengetahuan dan kemampuan yang sudah dimiliki diterapkan pada pemecahan masalah yang bersifat tidak rutin. Proses pembelajaran yang dilakukan guru sebaiknya diarahkan pada proses pemecahan masalah peserta didik.

Salah satu model pembelajaran yang berorientasi untuk pemecahan masalah dan studen centered adalah model problem based learning (PBL) atau pembelajaran berbasis masalah. Berdasarkan definisi Savery (2006), problem based learning adalah pembelajaran yang berpusat pada peserta didik dengan memberdayakan peserta didik untuk melakukan penelitian, mengintegrasikan teori dan praktek, dan menerapkan pengetahuan dan keterampilan untuk mengembangkan solusi yang layak untuk masalah yang didefinisikan.

Berdasarkan (Kemendikbud, 2013) model problem based learning adalah model pembelajaran yang dirancang agar peserta didik mendapat pengetahuan penting, yang membuat mereka mahir dalam memecahkan masalah, dan memiliki model belajar sendiri serta memiliki kecakapan berpartisipasi dalam tim. Proses pembelajarannya menggunakan pendekatan yang sistemik untuk memecahkan masalah atau menghadapi tantangan yang nanti diperlukan dalam kehidupan sehari-hari. Padmavathy dan Mareesh (2013) menguraikan tahapan dalam pelaksanaan pembelajaran dengan model problem based learning yaitu pembelajaran dimulai dengan masalah yang harus dipecahkan, dan masalah ini diajukan sedemikian rupa sehingga peserta didik mendapatkan pengetahuan baru sebelum mereka dapat memecahkan masalah.

Dalam pembelajaran problem based learning peserta didik menafsirkan masalah, mengumpulkan informasi yang dibutuhkan, mengidentifikasi solusi yang mungkin, mengevaluasi pilihan-pilihan, dan menyimpulkan hasil pekerjaan. Amalludin, et al., (2016) menyatakan bahwa pembelajaran problem based learning mendorong peserta didik untuk belajar dan bekerjasama dalam kelompok untuk mencari pemecahan masalah-masalah di dunia nyata sehingga kemampuan peserta didik seperti pemecahan masalah berkembang positif.

\section{Asesmen Diagnostik}

Menurut Wahyudi (2010) pengertian diagnostik dalam bidang pendidikan adalah suatu cara untuk menentukan kesulitan yang dialami oleh peserta didik agar dapat ditentukan terapi yang sesuai dengan kesulitan yang dialami oleh peserta didik tersebut. Kesulitan yang hendak dipantau adalah kesulitan yang terjadi pada proses belajar yaitu kesulitan belajar. Mengatasi kesulitan belajar, perlu adanya asesmen yang tepat untuk mengidentifikasi letak kesulitan belajar dalam hasil belajar matematika peserta didik. Dalam hal ini peneliti menggunakan asesmen/penilaian diagnostik. Instrumen yang digunakan adalah tes diagnostik.

Menurut Bruecker \& Melby dalam (Suwarto,2013), tes diagnostik digunakan untuk menentukan elemen-elemen dalam suatu mata pelajaran yang mempunyai kelemahan-kelemahan khusus dan menyediakan alat untuk menemukan penyebab kekurangan tersebut. Zhongbao Zhao (2013) menyatakan bahwa tes diagnostik utamanya adalah untuk mengetahui kekuatan dan kelemahan peserta didik dan memberi masukan kepada guru dan peserta didik untuk membuat keputusan terkait dengan perbaikan proses mengajar dan proses belajar.Menurut Geller, Leanne R. Ketterlin \& Paul Yovanoff (2009) dalam suatu pengambilan keputusan model pembelajaran, hasil tes diagnostik pembelajaran perbaikan, yang dalam hal ini adalah berupa remedial teaching. 


\section{Pemberian Teaching \\ Perlakuan}

Kegiatan guru menindaklanjuti hasil tes diagnostik peserta didik berupa perlakuan-perlakuan yang sesuai dengan permasalahan atau kesulitan yang dihadapi peserta didik. Kegiatan tidak lanjut dilakukan berdasarkan hasil analisis tes diagnostik secara cermat. Kegiatan tindak lanjut dapat dengan cara memberikan perlakuan khusus yang berupa kegiatan remidial teaching dikelas. Penentuan bentuk kegiatan remedial teaching juga bergantung pada karakteristik peserta yang mengalami kesulitan belajar.

Pemberian perlakuan remedial teaching merupakan suatu bentuk khusus pembelajaran yang diberikan kepada peserta didik yang mengalami kesulitan belajar melalui suatu pendekatan dan teknik tertentu (Irwantoro, 2016). Hal ini dimaksudkan untuk membetulkan dan memperbaiki atau menyembuhkan sebagian atau keseluruhan proses pembelajaran, sehingga peserta didik dapat mencapai hasil belajar sesuai dengan tujuan yang telah ditetapkan. Jadi pemberian perlakun remedial teaching adalah suatu sistem belajar yang dimaksudkan untuk mengoptimalisasikan prestasi belajar dengan cara mengidentifikasi kesulitankesulitan yang dialami oleh peserta didik, menemukan faktor-faktor penyebabnya, dan kemudian mengupayakan alternatifalternatif pemecahan masalah kesulitan belajar, baik dengan cara pencegahan maupun penyembuhan berdasarkan data dan informasi yang lengkap dan objektif.

Menurut Irwantoro (2016) dalam kaitannya dengan proses pembelajaran, fungsi remedial teaching diantaranya: fungsi korektif, fungsi pemahaman, fungsi pengayaan, fungsi penyesuaian, fungsi akselerasi, dan fungsi terapeutik. Beberapa metode yang dapat digunakan dalam pelaksanan remedial teaching menurut Kemendikbud (2013) antara lain sebagai berikut adalah metode pemberian tugas, metode tanya jawab, metode tutor sebaya, metode pengajaran individual, metode pemberian pengajaran ulang. Pemilihan metode remedial teaching berdasarkan hasil tes diagnostik dan tingkat kesulitan belajar peserta didik

\section{Kajian Penelitian yang Relevan}

Hasil penelitian Maretasani \& Dwijanto (2016) mengemukakan bahwa peserta didik yang memperoleh pembelajaran berbasis masalah dapat memecahkan masalah dengan lebih baik dibandingkan peserta didik dengan pembelajaran konvensional. Peserta didik dapat memahami soal dengan baik, merencanakan pemecahan masalah, melaksanakan pemecahan masalah dan memeriksa kembali. Peserta didik memiliki pengetahuan metakognisi antara pengetahuan deklaratif, pengetahuan kondisional maupun pengetahuan prosedural yang baik sehingga ia mampu mengatur proses kognitifnya untuk merencanakan, memeriksa dan mengevaluasi proses pemecahan masalah yang dilakukan oleh dirinya.

Hasil penelitian Vendiagrys, et al. (2015) menunjukkan bahwa peserta didik dengan gaya kognitif field independent dalam menyelesaikan masalah memiliki profil: dapat memahami pernyataan verbal dari masalah dan mengubahnya ke dalam kalimat matematika, lebih analitis dalam menerima informasi, dapat memperluas hasil pemecahan masalah dan pemikiran matematis, memberikan suatu pembenaran berdasarkan pada hasil, memecahkan masalah dalam konteks kehidupan nyata, dan memperoleh jawaban yang benar; sedangkan untuk peserta didik dengan gaya kognitif field dependent dalam menyelesaikan masalah memiliki profil: dapat memahami pernyataan verbal dari masalah, tetapi tidak dapat mengubahnya ke dalam kalimat matematika, lebih global dalam menerima informasi, mudah terpengaruh manipulasi unsur pengecoh karena memandang secara global, tidak dapat memperluas hasil pemecahan masalah, memberikan suatu pembenaran berdasarkan pada hasil, memecahkan masalah dalam konteks kehidupan nyata, dan sering tidak dapat memperoleh jawaban yang benar.

Hasil penelitian Geni \& Hidayah (2017) menunjukkan bahwa pembelajaran model problem based learning bernuansa etnomatematika efektif meningkatkan kemampuan pemecahan masalah matematika peserta didik; kemampuan pemecahan masalah peserta didik 
berdasarkan gaya kognitif, peserta didik dengan gaya kognitif field independent mampu memecahkan masalah dengan baik tetapi dalam menyusun dan menerapkan berbagai strategi pemecahan masalah masih belum optimal. Peserta didik dengan gaya kognitif field dependent mampu memecahkan masalah dengan cukup baik tetapi peserta didik belum lengkap menyusun strategi sehingga peserta didik mengalamikesalahan dalam menyelesaikan masalah dan peserta didik tidak dapat menerapkan berbagai strategi pemecahan masalah.

Hasil penelitian Festus (2013) menunjukkan bahwa pembelajaran matematika dengan model problem based learning merupakan strategi yang efektif untuk pembelajaran di kelas, secara umum penelitian ini menunjukkan bahwa peserta didik menjadi lebih aktif dalam proses pembelajaran. Hasil penelitian Noriza, et al., (2015) menunjukkan model pembelajaran berbasis masalah efektif terhadap kemampuan pemecahan masalah dan disposisi matematika, hal ini sesuai hasil penelitian Sulistiyoningsih, et al., (2015) yang mengemukakan Problem Based Learning bernuansa Adiwiyata dengan blended learning efektif meningkatkan kemampuan pemecahan masalah dan karakter peduli lingkungan.

Hasil penelitian Munir, et al., (2012) mengemukakan bahwa model pembelajaran berdasarkan masalah efektif untuk mengajarkan materi program linier dengan dipenuhinya syarat-syarat, aktifitas peserta didik dalam mengikuti pembelajaran mempunyai kategori tinggi, kemampuan guru mengelola pembelajaran kategori baik, respon peserta didik terhadap perangkat yang digunakan dalam pembelajaran persentasenya tinggi (merespon positif).

Hasil penelitian Setiawan, et al., (2014) menunjukkan bahwa model problem based learning berbasis nilai karakter berbantuan CD pembelajaran efektif terhadap kemampuan pemecahan masalah materi segiempat kelas VII.Hasil penelitian Hafid, et al., (2016) mengemukakan remedial teaching efektif dalam mengatasi kesulitan belajar, model pembelajaran yang dgunakan adalah pembelajaran kooperatif tipe Think Pair. Hasilnya kebanyakan letak kesulitan belajar peserta didik adalah pada tahap memahami (comprehension) dan tranformasi.

Hasil penelitian Saputra dan Suhito (2015) menunjukkan bahwa penerapan adaptive remedial teaching strategy berlatar pembelajaran aktif berhasil menyembuhkan kesulitan belajar matematika 10 dari 12 peserta didik yang mengalami kesulitan belajar dan $75 \%$ peserta didik berkesulitan belajar akibat pengaruh internal dan 25\% peserta didik berkesulitan belajar internal akibat pengaruh eksternal. Prasetyo, et al., (2016) melakukan penelitian tentang penerapan model remedial teaching berbasis web pada materi rumus dan fungsi kelas VIII SMP Negeri 2 Wuryantoro Kabupaten Wonogiri. Hasil penelitiannya menunjukkan remedial teaching berbasis web dapat meningkatkan hasil belajar peserta didik pada materi rumus dan fungsi.

Pada penelitian ini, peneliti akan menganalisis secara lebih mendalam tentang kemampuan pemecahan masalah matematika ditinjau dari gaya kognitif peserta didik pada pembelajaran model problem based learning yang disertai dengan pemberian perlakuan remedial teaching sebagai tindak lanjut dari asesmen diagnostik terhadap kesulitan belajar peserta didik

\section{METODOLOGI}

\section{a. Populasi dan Sampel}

Penelitian dilaksanakan di SMA N 1 Bojong pada kelas XI MIPA tahun pelajaran 2017/2018 dengan materi program linear. Populasi dalam penelitian ini adalah seluruh peserta didik kelas XI MIPA SMA N 1 Bojong. Sampel penelitian adalah kelas XI MIPA-4 sebagai kelas kontrol dan XI MIPA5 sebagai kelas eksperimen. Subjek penelitian dipilih dari kelas eksperimen (XI MIPA-5) yang dikelompokkan berdasarkan gaya kognitif field independent dan field dependent. Subjek penelitian yang dipilih adalah tiga peserta didik dengan gaya kognitif field independent tiga peserta didik dengan gaya kognitif field dependent dengan skor tes GEFT tertinggi, tengah dan terendah.

\section{b. Desain Penelitian}

Penelitian ini merupakan penelitian mixed method tipe concurrent embedded dimana penelitian kualitatif sebagai metode 
primer dan penelitian kuantitatif sebagai metode sekunder. Penelitian kualitatif untuk menganalisis kualitas pembelajaran, menganalisis kemampuan pemecahan masalah matematika peserta didik ditinjau dari gaya kognitif pada pembelajaran model problem based learning yang disertai dengan pemberian perlakuan remedial teaching dan mendeskripsikan proses pemberian remedial teaching. Penelitian kuantitatif dalam penelitian ini sebagai data penunjang untuk menganalisis kemampuan pemecahan masalah matematika peserta didik ditinjau dari gaya kognitif. Penelitian kuantitatif yang digunakan adalah alternative treatment post-test-only with nonequivalent group design.

\section{c. Alur Pengolahan Data}

Penelitian diawali dengan tahap studi pendahuluan dalam rangka mengidentifikasi masalah yang terjadi dilapangan dengan cara melakukan wawancara dan mengamati salah satu guru matematika SMA Negeri 1 Bojong saat mengajar, menyusun teori yang berkaitan dengan masalah yang akan diteliti dan menyusun perangkat pembelajaran dan instrumen penelitian yakni Silabus, RPP, Bahan Ajar, Lembar Kerja Peserta Didik, Lembar Validasi Perangkat Pembelajaran, Lembar Validasi Instrumen Penelitian, Tes Diagnostik, Tes Kemampuan Pemecahan Masalah Matematika (TKPM), Pedoman Wawancara, Lembar Pengamatan Keterlaksanaan Pembelajaran, Lembar Observasi Aktivitas Peserta Didik dan Angket Respon Peserta Didik Terhadap Pembelajaran. Kemudian melakukan uji validitas ahli untuk perangkat pembelajaran dan instrumen penelitian, dan uji coba soal TKPM. Kriteria yang digunakan untuk menentukan apakah instrumen penelitian layak digunakan adalah jika instrumen tersebut memenuhi kriteria valid

Pada tahap kedua yaitu pengumpulan data kualitatif dan kuantitatif, peneliti melakukan penelitian secara kualitatif dan kuantitatif secara beriringan. Sumber data dalam penelitian ini adalah data hasil tes GEFT merupakan data mengenai jenis gaya kognitif, hasil tes diagnostik, lembar jawaban tes kemampuan pemecahan masalah matematika (TKPM), lembar pengamatan keterlaksanaan pembelajaran, lembar angket respon siswa dan hasil wawancara peserta didik. Berdasarkan data tersebut akan dideskripsikan kemampuan pemecahan masalah matematika ditinjau dari gaya kognitif peserta didik.

Pada tahap analisis dan interpretasi data dilakukan berdasarkan data yang diperoleh pada tahap kedua, baik secara kualitatif maupun kuantitatif. Analisis secara kualitatif dilakukan untuk menganalisis kualitas pembelajaran model problem based learning yang disertai pemberian perlakuan remedial teaching dan mengetahui letak, faktor penyebab kesulitan belajar beserta proses remedial teaching peserta didik yang menjadi subjek penelitian sedangkan analisis secara kuantitatif dilakukan untuk menguji keefektifan pembelajaran model problem based learning yang disertai pemberian perlakuan remedial teaching terhadap kemampuan pemecahan masalah matematika.Analisis data kuantitatif terdiri dari (1) analisis data awal, diperoleh dari hasil Penilaian Tengah Semester yang bertujuan untuk mengetahui kondisi awal kelas eksperimen dan kelas kontrol yang menggunakan uji normalitas, uji homogenitas, uji kesamaan rata-rata dan (2) analisis data akhir, diperoleh dari TKPM yang dilakukan setelah pelaksanaan pembelajaran pada kelas eksperimen dan kelas kontrol yang menggunakan uji proporsi ketuntasan kemampuan pemecahan masalah matematika, uji beda rata-rata kemampuan pemecahan masalah matematika, dan uji beda proporsi kemampuan pemecahan masalah matematika. Analisis data kualitatif mengikuti konsep Milles \& Huberman (2007) yang menggunakan tiga langkah utama yaitu reduksi data, penyajian data, dan penarikan kesimpulan.

\section{HASIL DAN PEMBAHASAN}

\section{a. Deskripsi Hasil Tes dan Analisis Kualitas Pembelajaran}

Pengelompokan peserta didik

berdasarkan gaya kognitif dilakukan sebelum pelaksanaan pembelajaran. Gaya kognitif peserta didik dikelompokkan menjadi dua kategori yaitu field independent dan field dependent berdasarkan hasil tes GEFT. Berdasarkan hasil tes GEFT diperoleh 10 peserta didik dengan gaya kognitif field independent dan 21 peserta 
didik yang memiliki gaya kognitif field dependent

Tujuan penelitian yang pertama yaitu menganalisis kualitas pembelajaran model problem based learning yang disertai dengan pemberian perlakuan remedial teaching terhadap kemampuan pemecahan masalah matematika peserta didik. Kualitas pembelajaran model problem based learning yang disertai dengan pemberian perlakuan remedial teaching diukur berdasarkan tiga tahap yaitu tahap perencanaan, tahap pelaksanaan, dan tahap penilaian. Kualitas pembelajaran model problem based learning yang disertai dengan pemberian perlakuan remedial teaching diperoleh hasil bahwa pada tahap perencanaan pembelajaran diperoleh rata-rata total nilai hasil penilaian perangkat pembelajaran dan instrumen penelitian adalah 4,25 termasuk dalam kategori baik.

Pada tahap pelaksanaan pembelajaran diperoleh rata-rata total nilai hasil observasi keterlaksanaan pembelajaran adalah $85,5 \%$ termasuk dalam kategori baik. Pelaksanaan model problem based learning yang disertai dengan pemberian perlakuan remedial teaching dapat berjalan dengan sangat baik karena adanya dukungan positif dari peserta didik untuk aktif selama proses pembelajaran. Karsim, et al., (2017) menyatakan bahwa pembelajara menggunakan model problem based learning melatih peserta didik untuk belajar mandiri, belajar berkelompok untuk mengembangkan kemampuan pemecahan masalah, memahami materi dan membangun pengetahuannya. Hal ini sesuai hasil penelitian Saputri M., Dwijanto. \& Mariani S (2016) yang menunjukkan bahwa aktivitas belajar berpengaruh terhadap kemampuan pemecahan masalah peserta didik. Hal ini juga sesuai dengan penelitian Setiawan, T., Sugianto, \& Junaedi (2012) yang menunjukkan keaktifan peserta didik dalam pembelajaran dengan pendekatan problem based learning dapat meningkatkan keterampilan higher order thinking peserta didik

Tahap penilaian pembelajaran dilihat respon peserta didik terhadap pembelajaran dan keefektifan pembelajaran. Hasil angket respon peserta didik, peserta didik memberikan respon yang baik terhadap pembelajaran dengan skor rata-rata $76,58 \%$.
Hal ini menunjukkan bahwa mayoritas peserta didik menilai pembelajaran yang telah dilaksanakan dengan baik.

Keefektifan pembelajaran dengan uji prasyarat kelas kontrol dan eksperimen berdistribusi normal dan homogen. Keefektifan pembelajaran dilihat dari hasil tes kemampuan pemecahan masalah matematika yaitu uji rata-rata diperoleh $t$ hitung $=6,722$ dan $\mathrm{t}$ tabel $=1,70$ sehingga $\mathrm{t}$ hitung $>\mathrm{t}$ tabel maka ditunjukkan bahwa rata-rata kemampuan kemampuan pemecahan masalah lebih dari KKM (68), untuk uji ketuntasan diperoleh nilai zhitung $=2,39$ sedangkan ztabel $=1,70$ sehingga $z$ hitung $>z$ tabel maka ditunjukkan bahwa $75 \%$ peserta didik kelas eksperimen tuntas secara klasikal, untuk uji beda rata-rata diperoleh thitung $=4,11$ sedangkan ttabel $=1,67$ sehingga t hitung $>$ $t$ tabel maka dapat ditunjukkan bahwa ratarata kemampuan pemecahan masalah matematika pada kelas eksperimen lebih baik dari pada peserta didik kelas kontrol, untuk uji beda proporsi diperoleh $\mathrm{z}$ hitung $=$ 3,79 dan $\mathrm{z}$ tabel $=1,64$ maka ditunjukkan bahwa proporsi ketuntasan kemampuan pemecahan masalah matematika peserta didik kelas eksperimen lebih dari proporsi ketuntasan kemampuan pemecahan masalah matematika kelas kontrol, untuk uji beda rata-rata diperoleh thitung $=4,11$ sedangkan ttabel $=1,67$ sehingga t hitung $>$ t tabel maka dapat ditunjukkan bahwa ratarata kemampuan pemecahan masalah matematika pada kelas eksperimen lebih baik dari pada peserta didik kelas kontrol.

Dari ketiga hasil perolehan tersebut, dapat disimpulkan bahwa pembelajaran model problem based learning yang disertai dengan pemberian perlakuan remedial teaching berkualitas. Hasil tersebut memberikan gambaran bahwa pembelajaran model problem based learning yang disertai dengan pemberian perlakuan remedial teaching dapat memberikan hasil yang lebih baik dalam meningkatkan kemampuan pemecahan masalah matematika peserta didik. Pembelajaran ini juga menggunakan LKPD yang dapat membantu pemahaman peserta didik. Hal ini sejalan dengan hasil penelitian Mariya, et al., 2013) yang menyatakan penggunaan LKPD membuat peserta didik lebih antusias mengikuti pembelajaran yang disampaikan 
guru. Hal ini sejalan dengan hasil penelitian Lestari, et al., (2016) bahwa penerapan model problem-based learning efektif dalam meningkatkan dengan kemampuan pemecahan masalah dan kemandirian belajar peserta didik. Hal tersebut sesuai dengan penelitian Zakaria \& Hidayah (2015), yang menyatakan pembelajaran matematika dengan pendekatan ilmiah berbantuan LKPD dapat meningkatkan karakter jujur dan pemecahan masalah peserta didik.

b. Deskripsi Proses Remedial Teaching

Selain menggunakan model PBL, keefektifan pembelajaran model problem based learning yang disertai perlakuan remedial teaching dipengaruhi oleh adanya adanya pemberian tes diagnostik yang tujuannya untuk mengetahui letak kesalahan siswa pada materi yang telah dipelajari yang ditindak lanjuti dengan pemberian perlakuan remedial teaching. Pada penelitian ini, proses pemberian remedial teaching dilakukan dengan cara mengelompokkan peserta didik yang mempunyai kesulitan belajar yang sama. Peserta didik yang menghadapi kesulitan belajar dikelompokkan pada kelompok tertentu dan jenis remediasi yang diberikan bergantung pada macam materi pelajaran yang akan disembuhkannya.

Pelaksanaan pemberian remedial teaching yang dilaksanakan setelah tes diagnostik bagi peserta didik yang belum tuntas. Pemberian perlakuan remedial teaching dilakukan dengan metode belajar kelompok yang dikombinasikan dengan metode tutor sebaya, metode pemberian tugas, metode tanya jawab. dan metode pengajaran individual bagi beberapa peserta didik yang mempunyai banyak kesalahan atau kesulitan belajar. Lestanti, et al., (2016) menyatakan bahwa interaksi yang terjadi saat bekerja berkelompok antara lain adanya tanya jawab, saling berpendapat, menghargai pendapat dari teman yang lain, dan bekerja sama untuk memecahkan masalah matematika dapat mengembangkan kemampuan pemecahan masalah matematika.Metode tutor sebaya dalam remedial teaching juga berpengaruh positif, hal ini sesuai dengan hasil penelitian Nofitasari, et al., (2015) yang menyatakan bahwa pada model pembelajaran dengan menggunakan tutor sebaya dapat meningkatkan kemampuan pemecahan masalah peserta didik. Hal ini sejalan dengan penelitian Izzati (2015) menyatakan bahwa program remidial dan pengayaan dengan metode tutor sebaya berpengaruh dengan terhadap hasil belajar matematika.

Setelah pemberian perlakuan remedial teaching maka dilakukan tes evaluasi pasca remedial teaching. Tes evaluasi pasca remedial teaching dilakukan untuk mengetahui peserta didik sudah sembuh dari kesulitannya dan mengusai indikator materi yang belum tuntas pada tes diagnostik. Pemberian perlakuan remedial teaching berpengaruh signifikan dalam meningkatkan kemampuan pemecahan masalah. Hal ini sejalan dengan penelitian yang dilakukan oleh Karibasappa (2008) menunjukkan bahwa siswa yang diberikan pembelajaran remedial menunjukkan peningkatan yang signifikan secara operasional dan keterampilan matematika. Hal ini didukung penelitian yang dilakukan oleh Saputra \& Suhito (2015), yang menyatakan bahwa Adaptive Remedial Teaching Strategy berlatar pembelajaran aktif efektif dalam mengatasi kesulitan belajar matematika. Hal ini juga sesuai dengan pendapat Kartono, et al., (2016) menyatakan bahwa pemberian remedial teaching efektif untuk meningkatkan pencapaian hasil belajar peserta didik. Hasil penelitian Hafid, et al., (2016) juga mengemukakan bahwa remedial teaching efektif dalam mengatasi kesulitan belajar.

\section{c. Analisis Kemampuan Pemecahan Masalah Ditinjau Gaya Kognitif.}

Data kemampuan pemecahan masalah peserta didik berdasarkan gaya kognitif data tentang kemampuan peserta didik dalam menyelesaikan TKPM yang mencakup empat indikator pemecahan masalah menurut NCTM yaitu membangun pengetahuan matematika baru melalui pemecahan masalah, memecahkan masalah yang ada pada matematika dan bidang lain, menerapkan dan menyesuaikan diri dengan berbagai macam strategi pemecahan masalah, memonitor dan merefleksikan proses pemecahan masalah matematika, berikut persentase skor peserta didik pada tiap indikator pemecahan masalah ditinjau dari gaya kognitif peserta didik yang tercantum pada Gambar 1. 


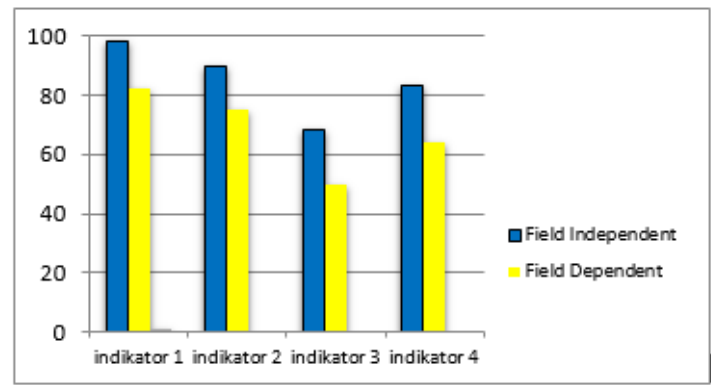

Gambar 1 Diagram Kemampuan Pemecahan Masalah Kelas Eksperimen ditinjau dari Gaya Kognitif Peserta didik

Dari Gambar 1 menunjukkan bahwa peserta didik dengan gaya kognitif field independent dapat mencapai indikator pemecahan masalah lebih baik daripada peserta didik dengan gaya kognitif field dependent. Pada indikator ketiga yang merupakan indikator yang memiliki pencapaian terendah dari kedua gaya kognitif tersebut. Indikator pemecahan masalah yang ketiga adalah menerapkan dan menyesuaikan berbagai macam strategi pemecahan masalah, peserta didik dengan gaya kognitif field independent dan peserta didik dengan gaya kognitif field dependent kurang mampu dalam menentukan langkah yang berbeda untuk menyelesaikan masalah. Kemampuan pemecahan masalah peserta didik berdasarkan gaya kognitif, peserta didik dengan gaya kognitif field independent mampu memecahkan masalah dengan baik tetapi dalam menyusun dan menerapkan berbagai strategi pemecahan masalah masih belum optimal. Peserta didik dengan gaya kognitif field dependent mampu memecahkan masalah dengan cukup baik. Peserta didik belum lengkap menyusun strategi sehingga peserta didik mengalami kesalahan dalam menyelesaikan masalah untuk beberapa permasalahan dan peserta didik tidak dapat menerapkan berbagai strategi pemecahan masalah.

Subjek field independent dan field independent mampu memahami masalah dengan menentukan informasi yang diketahui dan ditanyakan dalam masalah dengan baik, subjek field independent cenderung analitis sedangkan subjek field dependent cenderung menuliskan hal yang sama terhadap apa yang ada dalam soal. Pada tahap menyusun rencana pemecahan masalah subjek field independent dapat memanfaatkan informasi yang ada untuk menyusun rencana penyelesaian masalah dengan lengkap dan sistematis sedangkan subjek field dependent menuliskan rencana penyelesaian secara umum seperti pada soal dan kurang lengkap. Pada tahap melaksanakan rencana penyelesaian, subjek field independent mampu menerapkan langkah-langkah pemecahan masalah dan rumus yang telah direncanakan dengan benar dan dapat memperoleh hasil yang benar sedangkan subjek field dependent kurang mampu dalam menerapkan langkahlangkah pemecahan masalah yang telah direncanakan. Pada tahap memeriksa kembali subjek field independent dapat menuliskan kesimpulan yang diperoleh dengan baik dan dapat menyusun rencana pemecahan masalah dengan langkah yang berbeda sedangkan subjek field dependent kurang mampu dalam memeriksa kembali rencana dan proses pemecahan masalah, karena banyak melakukan kesalahan dalam perhitungan. Hal ini sesuai dengan pedapat Prabawa \&Zaenuri (2017) yang menyatakan subjek field dependent cenderung kurang dapat memeriksa kembali dan menuliskan kesimpulan dari pekerjaannya dan cenderung belum mampu menuliskan kesimpulan dengan jawaban yang tepat

\section{KESIMPULAN DAN SARAN}

\section{a. Kesimpulan}

Berdasarkan hasil penelitian dan pembahasan diperoleh kesimpulan sebagai berikut :

1. Pembelajaran model problem based learning yang disertai perlakuan remedial teaching terhadap kemampuan pemecahan masalah matematika siswa adalah berkualitas. Hal ini ditunjukkan dengan hal-hal berikut (a) Rata-rata total nilai hasil penilaian perangkat pembelajaran dan instrumen penelitian termasuk dalam kategori baik sehingga dapat disimpulkan bahwa tahap perencanaan atau persiapan yang telah dilakukan adalah berkualitas; (b) Rata-rata total nilai hasil observasi keterlaksanaan pembelajaran pada empat pertemuan termasuk dalam kategori baik dan dari angket respon peserta didik, peserta didik memberikan respon yang baik terhadap pembelajaran sehingga dapat disimpulkan bahwa tahap pelaksanaan 
yang dilakukan adalah berkualitas; (c) Tahap penilaian pembelajaran model problem based learning yang disertai pemberian perlakuan remedial teaching terhadap kemampuan pemecahan masalah matematika peserta didik yang telah dilakukan menunjukkan hasil bahwa persentase peserta didik pada kelas pembelajaran model problem based learning yang disertai pemberian perlakuan remedial teaching yang mencapai ketuntasan minimal 68 melampaui $75 \%$, rata-rata kemampuan pemecahan masalah matematika peserta didik pada kelas pembelajaran model problem based learning yang disertai pemberian perlakuan remedial teaching lebih baik daripada rata-rata kemampuan pemecahan masalah matematika peserta didik pada kelas pembelajaran model problem based learning yang tidak disertai pemberian tes diagnostik dan perlakuan remedial teaching dan proporsi ketuntasan kemampuan pemecahan masalah matematika peserta didik pada kelas pembelajaran model problem based learning yang disertai pemberian perlakuan remedial teaching lebih baik daripada proporsi ketuntasan kemampuan pemecahan masalah matematika peserta didik pada kelas pembelajaran model problem based learning yang tidak disertai pemberian tes diagnostik dan perlakuan remedial teaching.

2. Adanya pemberian tes diagnostik dan perlakuan remedial teaching efektif untuk meningkatkan kemampuan pemecahan masalah matematika pada pembelajaran problem based learning,

3. Kemampuan pemecahan masalah subjek field independent lebih baik daripada peserta didik subjek field dependent. Subjek field independent mampu menguasai dengan baik empat indikator kemampuan pemecahan masalah menurut NCTM (2000), sedangkan subjek field dependent belum mampu menguasai dengan baik keempat indikator kemampuan pemecahan masalah tersebut.

\section{b. Saran}

Berdasarkan simpulan yang diperoleh, peneliti memberikan saran-saran yaitu (1) Penggunaan model model problem based learning yang disertai pemberian perlakuan remedial teaching dinilai berkualitas dan dapat meningkatkan kemampuan pemecahan masalah matematika. Oleh karena itu, model tersebut dapat dijadikan pilihan dalam pembelajaran yang bertujuan meningkatkan kemampuan pemecahan masalah peserta didik; (2) Perbedaan gaya kognitif peserta didik mempengaruhi usaha peserta didik untuk memecahkan masalah, sehingga guru dapat mengarahkan peserta didik untuk menyelesaikan masalah sesuai dengan karakter gaya kognitif peserta didik dan memberikan bimbingan yang lebih pada peserta didik dengan gaya kognitif field dependent.

\section{UCAPAN TERIMA KASIH}

Terima kasih kepada reviewer jurnal EduMa: Mathematics Education Teaching and Learning atas kritik dan sarannya, terima kasih kepada Prof. Dr. Kartono, M.Si selaku pembimbing I dan Dr. Isti Hidayah, M.Pd selaku pembimbing II yang telah membimbing penelitian dan penulisan artikel ini.

\section{DAFTAR PUSTAKA}

Abdullah. D.I., Mastur .Z.\& Sutarto. 2015. Keefektifan Model Pembelajaran Problem Based Learning Bernuansa Etnomatika Terhadap kemampuan Pemecahan Masalah Siswa Kelas VIII. UJME, 4 (3): 285 -291.

Amalludin. S., Pujiastuti., Veronica. R.B. 2016. Keefektifan Problem Based Learning Berbantu Fun Math Book Terhadap kemampuan pemecahan Masalah Siswa kelas VIII. UJME, 5 (1): 69 - 76.

Akinmola, E.A. 2014. Developing Mathematical Problem Solving Ability: A Panacea for A Sustainable Develoment in The 21th Century. International Journal of Education and Research, 2(2): 1 - 8.

Crozier, W.R. 1997. Individual Learners: Personality Differences In Education. London: Routledge 
Festus, A.B. 2013. Activity-Based Learning Strategies in Mathematics Classroom. Journal of Education and Practice, 14(13): 8 -14.

Geller, L.R \& Paul Yovanoff. 2009. Diagnostic Assessment in Mathematics to Support Instructional Decision Making. Practical Assesment, Research \& Evaluation, 14(16):1-11.

Geni. P.R.L,\& Hidayah.I. 2017. Kemampuan Pemecahan Masalah Siswa pada Pembelajaran Problem Based Learning Bernuansa Etnomatematika Ditinjau dari Gaya Kognitif. UJMER, 6(1): 11-17.

Hafid, Kartono \& Suhito. 2016. Remedial Teaching Untuk Mengatasi Kesulitan Belajar Siswa Pada Kemampuan Pemecahan Masalah Matematika Berdasarkan Prosedur Newman. UJME, 5 (3):257-265.

Hmelo-Silver. 2004. Problem Based Learning: What and How do Students Learn?. Educational Psichology Review, 16(3): 235 - 266.

Irwantoro, N., Suryana, Y. 2016. Kompetensi Pedagogik Untuk Peningkatan dan PenilaianKinerja Guru dalam Rangka Implementasi Kurikulum Nasional. Surabaya: Genta Group Production.

Izzati. 2015. Pengaruh Penerapan Program Remidial dan Pengayaan Melalui Pembelajaran Tutor Sebaya Terhadap Hasil Belajar Matematika Siswa. Jurnal EduMa, 4(1): 54-68.

Joseph, Y.K. 2011. An Exploratory Study of Primary Two Pupils' Approach to Solve Word Problems. Journal of Mathematics Education,12(1):19-30.

Karibasappa, C.N et.al. 2008. A Remedial Teaching Programme to Help Children with Mathematical Disability. Asia Pacific Disability Rehabilitation Journal, 19(.2).

Karsim, Suyitno. H.,\& Isnarto. 2017. Pengaruh IQ dan Disposisi Matematis Terhadap Kemampuan Pemecahan Masalah Peserta Didik Kelas VII Melalui Model Pembelajaran PBL Berbantuan LKPD.UJME,6(3):352-359.

Kartono, Rizki, A.N., \& Suhito. 2016. The effectiveness of Remedial Teaching Based Diagnostic Assessment on The Achievement Student Mathematics Learning Outcomes in Inquiry Learning Model.IJARIIE, 2(4): 478- 484.
Khaerunisak.,Kartono,Hidayah.I., \& Fahmi. A.Y.2017. The Analysis of Diagnostic Assesment Result in PISA Mathematical Literacy Based on Student Self-Efficacy in RME Learning.Journal of Mathematics Education,6(1) : 77 -94.

Kemendikbud. 2013. Panduan Remedial dan Pengayaan. Jakarta: Direktorat Pembinaan SMA

Lestanti., Isnarto., \& Supriyono. 2016. Analisis Kemampuan Pemecahan Masalah Ditinjau Dari Karakteristik Cara Berpikir Siswa Dalam Model Problem Based Learning. UJME, 5(1):16-23.

Lestari, P.D., Dwijanto, \& Hendikawati, P. 2016. Keefektifan Model Problem-Based Learning Dengan Pendekatan Saintifik Terhadap Kemampuan Pemecahan Masalah Dan Kemandirian Belajar Peserta Didik Kelas VII. UJME, 5 (2) :146 - 153

Maretasani, L. D., \& Dwijanto. 2016. Kemampuan Pemecahan Masalah dan Metakognisi Berdasarkan Orientasi Tujuan Pada Pembelajaran Berbasis Masalah. UJMER 5 (2):139 -147.

Mariya, D., Mastur.Z.,\&Pujiastuti. 2013. Keefektifan Pembelajaran SAVI Berbantuan Alat Peraga TerhadapKemampuan Pemecahan Masalah.Kemampuan Pemecahan Masalah Materi Segiempat kelas VII.UJME, 2(2): 40-47.

Milles, M. B., \& Huberman, A. M. 2007. Analisis Data Kualitatif. Terjemahan Tjetjep Rohendi Rohidi. Jakarta: UIPress.

Mulyadi. 2010. Diagnosis Kesulitan Belajar dan Bimbingan terhadap Kesulitan Belajar Khusus.Yogyakarta: Nuhu Litera.

Munir M.,Widodo \& Wardono. 2012. Pengembangan Perangkat Pembelajaran Berdasarkan Masalah Pada materi Program Linear kelas XII. UJRME,1(1): 50-57.

National Council of Teacher of Mathematics. 2000. Principles and Standards for School Mathematics. Reston, VA: Author.

Nofitasari. L., Mastur. Z., \& Mashuri. 2015. Keefektifan Model Pembelajaran Tutor Sebaya Bernuansa Etnomatematika 
Terhadap Kemampuan Pemecahan Masalah Peserta Didik Pada Materi Segiempat. UJME, 5 (1):54-61.

Noriza, M.N, Kartono \& Sugianto.2015. Kemampuan Pemecahan Masalah dan Disposisi Matematis Siswa Kelas X pada Pembelajaran Berbasis Masalah. UJMER,4 (2):66-75.

OECD. 2012. PISA 2012 Assessment and Analytical Framework: Mathematics, Reading, Science, Problem Solving and Financial Literacy. Paris: OECD

OECD. 2015. PISA 2015 Assessment and Analytical Framework: Mathematics, Reading, Science, Problem Solving and Financial Literacy. Paris: OECD

Padmavanthy dan Mareesh.2013. Effectivenes of Problem Based Learning in Mathematics. International Multidisciplinary e-Journal, 2(1):45-51.

Permendikbud Nomor 21 Tahun 2016 tentang Standar Isi untuk Satuan Pendidikan Dasar dan Menengah. 2016.

Prabawa, E.A.\& Zaenuri. 2017. Analisis Kemampuan Pemecahan Masalah Ditinjau dari Gaya Kognitif Siswa pada Model Project Based Learning Bernuansa Etnomatematika. UJMER 6 (1): $120-129$.

Prasetyo, R. I., Supraptono, E., \& Utami, A,D. 2016. Penerapan Model Pembelajaran Remedial Berbasis Web Pada Materi Rumus dan Fungsi .Dinamika, 6(2):51-57

Saputra, A.D. \& Suhito. 2015. Keefektifan Adaptive Remedial Teaching Strategy berlatar Pembelajaran Aktif dalam Mengatasi Kesulitan Belajar Matematika Jurusan IPS. UJME 4 (1): 1-10.

Saputri M., Dwijanto., \& Mariani S. 2016. Pengaruh PBL Pendekatan Kontekstual Strategi Konflik Kognitif dan Kemampuan Awal Terhadap Kemampuan Pemecahan Masalah Siswa Materi Geometri. UJME 5 (1): 7783.

Satoto, S., Sutarto, H., \& Pujiastuti. E. 2013. Analisis Kesalahan Hasil Belajar Siswa dalam Menyelesaikan Soal dengan Prosedur Newman.UJME, 1 (2):1-7.

Savery. 2006. Overview of Problem-based Learning: Definitions and Distinctions. Interdisciplinary Journal, 1(1): 9-20.
Setiawan .D, Waluya .B, \& Mashuri. 2014. Keefektifan PBL Berbasis Nilai Karakter Berbantuan CD Pembelajaran Terhadap kemampuan pemecahan Masalah Materi Segiempat kelas VII. UJME 3 (1):15-20.

Setiawan,.T., Sugianto, \& Junaedi, I. 2012. Pengembangan Perangkat Matematika Dengan Pendekatan Problem Based Learning untuk Meningkatkan Keterampilan Higher Order Thinking. UJRME 1 (1) : 72 - 80.

Suherman, I.,Turmudi.,Suryadi,D.,Herman, T., Suhendra., Prabawanto, S., Nurjanah., \& Rohayati, A. 2003. Strategi Pembelajaran Matematika Kontemporer. Bandung: UPI.

Sulistiyoningsih. T, Kartono, \& Mulyono. 2015.PBL Bernuansa Adiwiyata dengan Blended Learning untuk Meningkatkan Kemampuan Masalah dan Karakter Peduli Lingkungan. UJMER,4(2):84-92.

Suwarto.2013. Pengembangan Tes Diagnostik. Jurnal Pendidikan 22(2): 187-202.

Vendiagrys, L., I. Junaedi, \& Masrukan. 2015. Analisis Kemampuan Pemecahan Masalah Matematika Soal Setipe TIMSS berdasarkan Gaya Kognitif Siswa pada Pembelajaran Model Problem Based Learning.UJMER 4(1): 34-41.

Wahyudi. 2010. Assesment Pembelajaran berbasis Portofolio di Sekolah.Visi Ilmu Pendidikan. 2(1): 288 -296.

Witkin, H.A.1977.Field-Dependence and Field-Independence Cognitive Styles and Their Educational Implications. Review of Educational Research, 47(1): 1- 64.

Zakaria F., \& Hidayah. I. 2015. Pembelajaran Matematika dengan Pendekatan Ilmiah Berbantuan LKPD untuk Meningkatkan Karakter Jujur dan Pemecahan Masalah Bagi Siswa SMP. UJME 4 (1):32-40.

Zhao, Zhangbao. 2013. An Overview od Studies on Diagnostic Testing and its Impplications for the Development of Diagnostic Speaking Test. International Journal of English Linguistics 3(1): 4145 